\title{
Eyes and speech in English, Finnish and Czech children's literature $^{1}$
}

The fires of fury and hatred were smouldering in her small black eyes. "Matilda!" she barked.

"Stand up!"

[Roald Dahl, Matilda, 1988]

\author{
Anna Čermáková, Markéta Malá \\ Charles University, Prague (Czech Republic)
}

This study explores cross-linguistically, in English, Czech and Finnish, eye-behaviour that occurs in children's fiction in the vicinity of character speech. We explore how authentic eye behaviour, as an important part of non-verbal communication, is rendered in fictional worlds. While there are more similarities than differences across the languages in the characteristics and narrative functions of fictional eye-behaviour, the linguistic encoding differs substantially due to typological differences between the languages. The same semantic roles are often expressed by divergent syntactic means. The divergence is reflected primarily in the relative weight of different word-order principles, the different means of indicating simultaneity, as well as the role of inflection in Finnish and Czech.

Keywords: fictional speech, eye-behaviour, gaze, children's literature, language typology, Czech/English/Finnish

\section{Introduction}

The description of the scene in the quote above from Roald Dahl's iconic text, where the smouldering fires of fury and hatred in Miss Trunchbull's small black eyes as she barks at Matilda to stand up allows us to fully immerse in the moment of confrontation between Miss Trunchbull and Matilda. The tense atmosphere is created with the use of a very short emphatic direct speech graphically emphasised by the use of exclamation marks. The direct speech is introduced by a body language description with a focus on eye-behaviour, then it is interrupted by an expressive reporting clause (she barked), which suggests that the speech is loud and

\footnotetext{
${ }^{1}$ This research was supported by the European Regional Development Fund project 'Creativity and Adaptability as Conditions of the Success of Europe in an Interrelated World' (reg. no.: CZ.02.1.01/0.0/0.0/16_019/0000734), the programme 'Progres Q08 Czech National Corpus, 'Progres Q10 Language in the shiftings of time, space, and culture', and 'Progres Q17 The Teachers Preparation and Profession in the Context of Science and Research' implemented at Charles University.
}

CROSSING THE BORDERS: ANALYSING COMPLEX CONTRASTIVE DATA. Edited by Anna Čermáková, Signe Oksefjell Ebeling, Magnus Levin and Jenny Ström Herold. BeLLS Vol 11, No 1 (2021), DOI: 10.15845/bells.v11i1.3444. Copyright (C) by the author. Open Access publication under the terms of CC-BY-NC-4.0. 
aggressive. As readers, we can deduce a great deal of information about the event itself and the character of Miss Trunchbull.

This study is focused on fictional body language, and more specifically eye-behaviour that occurs in connection with fictional speech as illustrated in the above extract. Descriptions of body language in fiction are not only an important part of characterisation but they also refer to the physical body of fictional characters and describe how fictional people relate to each other. In fictional texts, body language descriptions play a particularly important role in connection with speech because they contribute to the effect of its authenticity. While the authenticity of fictional speech has been studied extensively (see, for example, Mahlberg et al., 2019), we will, drawing on Argyle's (2010) framework of bodily communication, examine how the fictional eye-behaviour resembles the authentic and what linguistic means typologically different languages use to encode the eye-behaviour in fiction.

The study is a contrastive one. We will examine fictional eye-behaviour across three languages: English, Czech and Finnish. While we can hypothesise there will not be substantial cultural differences in the types of eye-behaviour described because all three languages belong to low-contact cultures (Argyle, 2010), we can expect substantial linguistic differences due to the different language typologies represented. English is a predominantly analytic Germanic language with fixed word order, Czech is a West Slavic inflectional language with free word order and Finnish is an agglutinative Finno-Ugric language.

The study relies on data from comparable corpora of non-translated children's fiction. Children's literature is a specific text-type in several respects. Its intended readers are only gradually developing their reading and cognitive skills, and also real-life knowledge Nikolajeva (2014) refers to them as 'novice readers'. It is therefore expected that the linguistic make-up of these texts will reflect the readership. The language of children's literature has received surprisingly little attention (see, for example, Stephens, 2004; Wild et al., 2013) and even less so cross-linguistically (but see, for example, Čermáková and Chlumská, 2017). ${ }^{2}$ One of the features that has been expected and observed is a greater degree of explicitness than in texts written for adult readers (Šebestová and Malá, 2019). While fictional body language is difficult to describe systematically because of its variety of forms (see Mahlberg et al., 2020; Čermáková and Mahlberg, forthcoming), we assume that children's fiction includes eyebehaviour descriptions that are accessible to the 'novice reader' and will thus constitute a suitable data-source for mapping this phenomenon cross-linguistically.

'Eyes' are one of the most frequently mentioned body parts in fictional texts and looking, or 'gaze', "is of central importance in social behaviour" (Argyle, 2010: 153). The eyes are also one of the most important channels for the expression of emotions (ibid.: 5). Understanding norms of social behaviour and encoding of emotions are of crucial importance for a child's development. Children's fiction is one source that encodes these norms. The meaning making process, though it may be empirically "problematic to access and judge readers' cognitive and emotional engagement with texts" (Nikolajeva, 2014: 2), is based on the interaction between the information in the text and the reader's real-life knowledge. However, so far, less attention has been paid to "the profound difference between young and adult readers" (ibid.: 10). Nikolajeva explicitly inquires what happens when the "readers' capacity to engage with texts is absent or underdeveloped" and she asks "how texts may deliberately compensate for this obstacle" (ibid.), that is, what the meaning-making process of children is like and in what ways, if at all, children's texts support it.

In view of the above, we aim to answer the following research questions:

\footnotetext{
2 Translation of children's literature has received comparatively more attention, see, for example, Alvstad (2010), Lathey (2011), Čermáková and Mahlberg (2018).
} 
1. What are the lexico-grammatical similarities and differences in fictional eye-behaviour descriptions in the typologically different languages: English, Czech and Finnish?

2. What are the characteristics and narrative functions of fictional eye-behaviour descriptions across the three languages?

In Section 2, we describe the theoretical background of this study and in Section 3, the data and methodology used. Section 4 aims to answer our first research question and looks at lexicogrammatical similarities and differences across the three languages. Section 5 aims to answer our second research question and looks at the characteristics and narrative functions of fictional eye-behaviour. Section 6 offers conclusions and suggestions for further study.

\section{Body language and speech}

The centrality of character in fiction has been recognised for some time now; Stockwell and Mahlberg (2015: 130) suggest that "the relationship that readers develop with fictional characters is a main motivating factor in reading literature at all". We can assume that communication between characters is key for meaning making. Communication between real people is also something that children are exposed to daily and are learning to make sense of. The "meaningfulness" of fictional communication depends on "representing the kind of language which a reader can recognise, by observation, as being characteristic of a particular situation" (Leech and Short, 2007: 129).

The representation of characters' speech as part of characterisation has received considerable attention (Leech and Short, 2007; Semino and Short, 2004). One of the concerns has been the credibility and authenticity of its representation (McIntyre, 2016). While the overlap between fictional speech and "real" speech still lacks a large-scale systematic analysis (but see Mahlberg et al., 2019), Page (1988: 7-10) points to inherent characteristics of spoken language, such as pauses, repetitions, grammatical inconsistencies, its dependence on the shared context and the "phonological component" that make it difficult to adequately and meaningfully re-create in fictional writing. Some of these features may be, to a degree, recreated by graphical conventions, the choice of reporting verbs but also body language descriptions that accompany speech. In fictional texts, for example, suspensions have been identified as "associated with specific types of body language presentation" (Mahlberg et al., 2020: 150). A 'suspended quotation' is defined by Lambert (1981: 6) as "protracted interruption by the narrator of a character's speech". This is, according to Lambert (ibid.: 41), a place where details on suprasegmental and prosodic features of the speech frequently occur and contribute to describing dialogue that resembles an authentic one. Mahlberg et al. (2020: 150) stress that suspensions "can create an impression of simultaneity" - which can otherwise be challenging to the linear nature of the text.

Body language descriptions do not occur only in connection with speech. The body language of fictional characters reveals not only how the characters behave at a specific moment but also what the characters are like more generally. The most comprehensive descriptive framework of fictional body language was developed by Korte (1997). She (1997: 3-4) conceptualises body language "as non-verbal behaviour (movement and postures, facial expressions, glances and eye contact, automatic reactions, spatial and touching behaviour) which is 'meaningful' in both natural and fictional communication". Korte points out that "[i]n the context of speech, it also plays an important role in regulating the conversation; it communicates the listener's reactions to the speaker and can either complement, replace, or contradict a spoken message" (ibid.: 27). Eye-behaviour, similarly to facial expressions, is 
"extremely relevant in face-to-face interaction" (ibid.: 57). Korte (ibid.) specifically mentions three types of eye-behaviour: "gaze (one person looking at another person), mutual gaze or eye contact (two persons looking into one another's eyes), and avoiding gaze." The theory of gaze has received a great deal of critical attention, including corpus stylistic approaches to literary characterisation (Johansson and Håkansson, 2019).

Korte's (1997) body language classification framework is based on types and functions of authentic body language. For our descriptive framework, we similarly rely on authentic types and functions of bodily communication as suggested by Argyle (2010: 5) (for details see Section 5). For the descriptions of eye-behaviour the most relevant functions are expression of emotions, communication of interpersonal attitudes, and functions of supporting speech. Bodily communication varies across cultures, the greatest differences being between 'contact' and 'non-contact' cultures (e.g. Argyle, 2010: 57-61). However, the expression of emotion is similar across cultures with the main difference being the degree of expressiveness and restraint (ibid.: 66). Cultural variations include, for example, conventions about laughing and crying in public, but also linguistic categorization of emotions (ibid.: 128). The levels of gaze also vary between cultures. All cultures have norms that constrain gaze behaviour - "children are instructed to 'look at me', not to stare at strangers and not to look at certain parts of the body [...] people have to look in order to be polite, but not to look at the wrong people or in the wrong place" (ibid.: 158).

Linguistically, it has been shown that in fiction, body part nouns participate frequently in multi-word combinations, whether extended units of meaning (Sinclair, 2004: 31-35; Ebeling, 2014; Mahlberg et al., 2020), recurrent sequences of words or collocational patterns allowing for some variation (Mahlberg, 2013). Such recurrent patterns also provide general insights into fictional characters' characterisation and their communication (Mahlberg, 2020: 144). This seems to hold across languages (Vaňková et al., 2005; Stubbs, 2007; Lindquist and Levin, 2008; Wieçławska, 2012; Ebeling, 2014) and applies to children's literature too. The close connection between eye-behaviour and direct speech in children's literature is supported by the fact that in our BNC children's literature sub-corpus (for details see Section 3), the most frequent 4 -grams ${ }^{3}$ containing a form of the lemma EYE are <his eyes. '> and <her eyes. '>. Both include an opening single quotation mark as their last token, indicating the beginning of a direct speech, as in He glanced around slowly, blinking his eyes. 'What happened?' (CFJ). These patterns are in line with Mahlberg et al.'s (2020: 150) observation that "[it] is typically the narrator who describes characters' body language, while accounts of body language are less frequent in the speech of characters", which is also shown by the third person possessive pronouns.

\section{Data and methodology}

In this study, we focus on eye-behaviour that occurs exclusively in the vicinity of speech. We do not deal with verbs of 'looking'; but we specifically explore the lemma EYE, OKO and SILMÄ respectively. We use three broadly comparable datasets of children's fiction. For this study, children's fiction is, as a text-type, defined by its audience, as texts "written to be read by children and young people" (Reynolds, 2011: 1; for limitations of this definition see, e.g., Reynolds, 2011: 1-5). In our case, the study is substantially limited by text availability. We rely on corpus compilers and their classification. For English, we use the subcomponent of

\footnotetext{
3 The 4-grams (recurrent four-word sequences) were identified using the KonText interface; punctuation was treated as a word-token; the position of the lemma EYE in the 4-gram was not fixed.
} 
children's fiction ( 2 million words) ${ }^{4}$ in the British National Corpus (BNC), for Finnish, we use the subcomponent of original (non-translated) Finnish children's literature texts in the Savokorpus $^{5}$ ( 0.5 million words) and for Czech, we use a subcorpus of Czech children's books selected from the Czech National Corpus ${ }^{6}$ (2.8 million words). For an overview see Table 1 and for the detailed composition of the subcorpora see the Appendix. Both the BNC and the Czech data were examined using the KonText interface (Machálek, 2020), the Finnish data was processed with LancsBox (Brezina et al., 2018).

Table 1. Corpora used in the study.

\begin{tabular}{llll}
\hline & ENGLISH & CZECH & FINNISH \\
\hline Source corpus: & BNC subcorpus & Syn-7 subcorpus & Savokorpus \\
No. of words: & 2 mil. & 2.8 mil. & 0.5 mil. \\
No. of texts: & 77 & 59 & 24 \\
No. of authors: & $44+31$ adapted classics & 43 authors & 19 authors \\
Publication dates: & $1960-1994$ & $1967-2013$ & $1994-1999$ \\
\hline
\end{tabular}

Methodologically, Mahlberg et al. (2020: 144) make a strong case for a "lexically-driven approach that describes body language on the basis of repeatedly occurring linguistic patterns, in the form of repeated sequences of words". This approach has proven cross-linguistically extremely challenging between typologically different languages (for discussion see Čermáková and Chlumská, 2017; Šebestová and Malá, 2019). We, therefore, approach the analysis of eye-behaviour through the examination of the grammatical and textual functions of the nouns EYE, OKO and SILMÄ. We use lemmata because both Finnish and Czech have an extensive number of forms per noun. For each language, we first retrieved all occurrences of EYE, OKO and SILMÄ. These were further narrowed down only to occurrences of 'eyes' within the vicinity of speech, which we defined as a $+/-5$-word span from the beginning or end of direct speech. For each language, we have analysed a random sample of 100 concordance lines.

The English and Czech corpus data are lemmatised. There were 2,251 total occurrences of EYE, and OKO occurred 3,986 times. In English and Czech, direct speech is marked by quotation marks, so for the selection of the relevant occurrences, i.e. those in the vicinity of direct speech, we relied on punctuation. EYE occurred near speech 372 times and OKO 1,380 times. The concordance lines were shuffled and the initial 100 instances of EYE/OKO in the narrator's speech were selected for further analysis. For Finnish, we had unlemmatised data; we, therefore, searched in LancsBox for the word root $\left\langle\right.$ silm. $\left.{ }^{*}\right\rangle$ and relevant occurrences were selected manually. As the typographical conventions in Finnish do not use quotation marks, the relevant examples had to be extracted manually too; see example (1), where direct speech is marked in bold. After the examination of the results based on the query for the root 'silm', we identified 932 occurrences of SILMÄ. Further examination of these 932 instances for occurrences in the vicinity of speech narrowed our dataset to 168; out of this sample, we selected 100 examples aiming at even distribution across the source texts.

\footnotetext{
${ }^{4}$ The BNC subcorpus was defined on the basis of audience ('child/teenager'), domain ('imaginative') and medium ('book').

${ }^{5}$ Provided by the courtesy of Prof. Anna Mauranen.

${ }^{6}$ Available at www.korpus.cz. The subcorpus was defined on the basis of source language ('Czech'), audience ('children/teenagers'), text-type ('fiction'), and medium ('book').
} 
(1) Ai niin, käytännössä, sanoi Joulupukki ja hänen silmissään tanssi nauru. Käytännössä sinä lähdet ... [sla002]

[Well, in reality, the Father Christmas said and there was laughter in his eyes. - In reality, you will go ...]

The three 100-line samples were analysed from two points of view: a) the lexico-grammatical perspective (Section 4), and b) the eye-behaviour and narrative function perspective (Section 5). The lexico-grammatical analysis focuses on the relationship between the grammatical characteristics (syntactic function, case-marking, prepositions) and the lexico-grammatical patterns in which EYE, OKO and SILMÄ occur, with focus on the semantics of the co-occurring verbs.

For the analysis of the characteristics of fictional eye-behaviour we draw on authentic eye-behaviour, specifically types and functions of bodily communication as described by Argyle (2010: 5); for more details see Section 5.

\section{Lexico-grammatical perspective}

The lexico-grammatical perspective focuses on differences and similarities in syntactic structure in the three languages in relation to particular situations in which the eyes are involved, as indicated by the meaning of the predicate verb; here we also consider the information structure perspective.

\subsection{Syntactic functions}

As pointed out by Burgoon et al. (2010: 4-5), nonverbal behaviours, such as smiling, crying or staring in a threatening manner, "allow people to communicate with one another at the most basic level regardless of their familiarity with the prevailing verbal language system."

There are, however, differences in how the same eye-behaviour and communication are rendered by different languages, depending on their typological characteristics.

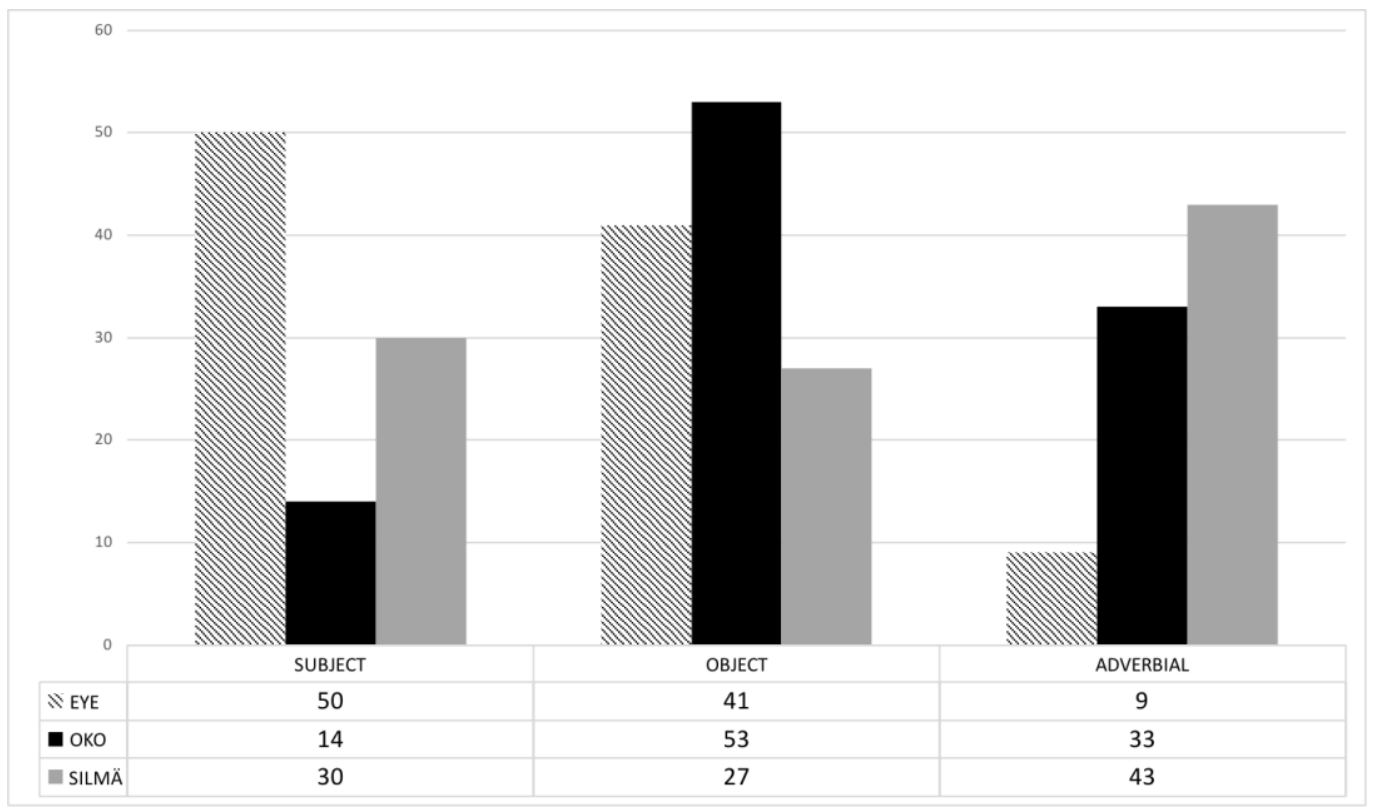

Figure 1. Syntactic functions of the 100 phrases comprising EYE, OKO and SILMÄ. 
While the 100 phrases with EYE, OKO and SILMÄ perform the same syntactic functions in English, Czech and Finnish, the distribution of the functions differs (cf. Figure 1), and so does the syntactic structure of the phrases. EYE, OKO and SILMÄ typically function as the head of a noun phrase. The syntactic function of the adverbial or object may be performed by a prepositional phrase with a prepositional complement realized by an EYE/OKO noun phrase in English and in Czech (e.g. into her eyes). In Finnish, the object is realised by SILMÄ in nominative, accusative or partitive case. The Finnish constructions 'silmät $+\mathrm{E}-$ infinitive instructive" (e.g. silmät palaen 'eyes shining') (example 2a) and 'silmät + adj._essive' (e.g. silmät suurina 'eyes big') ${ }^{8}$ (example 3a) were categorised as subjects analogically to corresponding structures in English (examples $2 \mathrm{~b}$ and $3 \mathrm{~b}$ respectively).

(2) a. Jassu kyseli silmät palaen ... [sla001] [Jassu was inquiring eyes E-INF.INSTRUCTIVE.-shining ...]

b. ... the doctor said, eyes twinkling [FSR]

(3) a. Anisa tuijotti silmät suurina hänen olkapäänsä yli. [sla010] [Anisa stared eyes ESS.-big across her shoulder]

b. Odhar continued, his eye hard on his son [APW]

In the 'subject' category, we have also included Czech and Finnish noun phrases where OKO or SILMÄ is a postmodifier/premodifier in the genitive case (e.g. tři páry prekvapených očí 'three pairs of GEN.-surprised eyes', silmien katse - 'look of GEN.-eyes'). No such subject phrases occurred in our English data.

There is a statistically significant difference between the number of EYE, OKO and SILMÄ phrases used as the subject in English (50 occurrences), Czech (14) and Finnish (30) respectively. There is no significant difference between adverbial uses in Czech and Finnish (33 and 43 cases respectively); English (9) differs significantly from both. While there is no significant difference in the object use in English and Czech (41 and 53), Finnish (27) differs significantly from both English and Czech. ${ }^{9}$

These differences can be ascribed to typological distinctions. English and Czech

involve different hierarchies of the operating word order principles: owing to its analytic character, English employs word order primarily to indicate grammatical functions; on the other hand in inflectional Czech the grammatical principle plays a secondary role, syntactic relations being indicated by grammatical endings. Hence Czech word order is free to perform other functions among which indication of the FSP ['functional sentence perspective', i.e. information structure] functions of the clause elements ranks highest. (Dušková, 2015: 14)

Finnish is closer to Czech with respect to the role of inflection and word order: it "exhibits relatively few constraints on word order in a finite clause [...], case suffixes guide arguments into their canonical positions [...], the word order correlates with discourse interpretation" (Brattico, 2020: 38-39). Word order in Finnish finite sentences is "constrained by information structure": there are "designated word order positions for the topic of the sentence and a phrase that carries a contrastive focus" (Nikanne, 2017: 69).

\footnotetext{
${ }^{7}$ E-infinitive is also referred to as II. infinitive.

${ }^{8}$ Hakulinen (ed.) (2004: 837 § 877) calls these 'status constructions', which have an adverbial function expressing state of being.

${ }^{9}$ The difference is statistically significant at the 0.05 level of significance (Log-likelihood). Cvrček, V. (2021). Calc: Corpus Calculator 1.02. Prague: Czech National Corpus (Available from https://www.korpus.cz/calc/) was used to calculate statistical significance.
} 


\subsection{The subject and the adverbial}

The most marked differences in the distribution of syntactic functions in the three languages are between the subject and adverbial. Half of the instances of EYE-phrases in our English sample function as the subject, occupying the initial position in the sentence. The 'eyes' are thematic elements, carrying a relatively low amount of information; their contextual dependence is signalled by anaphoric possessive determiners or definite articles, see example (4a). The predicate verb is typically intransitive or copular, with the absence of further complementation making it the most prominent, rhematic part of the message. Semantically, the EYE-subjects display a preference for predicates which express the emission of light, such as SHINE, BE BRIGHT or FLASH (see also Section 5.1.1 for discussion of light metaphor), movement or absence thereof: BE DRAWN, BE FIXED, BORE, CLOSE, NOT LEAVE, REACT, REST, RISE, ROLL, SEARCH, SLIDE, STAY, TURN, WANDER, and a change, usually in the shape of the eyes: BULGE, NARROW, ROUND, SHARPEN, SOFTEN.

The semantically corresponding situations may be rendered in Czech as clauses with a divergent syntactic structure. In clauses drawing on the light metaphor, the OKO-phrase is often constructed as an adverbial in Czech (example 4b). Although the syntactic structure is different in examples (4a) and (4b), the information structure is similar in the two languages. The clauseinitial position is occupied by a thematic, context bound element, expressing the location of the 'light'; the phrase functions syntactically as the subject (his eyes) in English and as the adverbial ( $v$ očich 'in eyes') in Czech. The locative semantics of the OKO-phrase is supported by the preposition $v$ ('in') and case marking (the locative case) in Czech. In both languages, the predicate verbs are intransitive ${ }^{10}$ and the predicates constitute the focus of the message.

In Finnish, in about a third of the occurrences where verbs of 'light' occur, the situation is syntactically very similar to Czech, and in terms of information structure it is similar to both Czech and English. 'Eyes' occur in sentence initial position in one of the 'locative' Finnish cases (inessive, illative, elative) ${ }^{11}$ see example (4c). In most of the remaining cases, Finnish is syntactically closer to English, 'eyes' occur as thematic in the subject position. For this semantic group of verbs, the typical construction in Finnish seems to be the E-infinitive in instructive case as in example (2a) above. (For a discussion of infinitives in Finnish see, for example, Toivonen, 1995; Hakulinen (ed.), 2004.)

(4) a. 'Great!' cried Mould. His eyes shone brighter ... [AMB]

b. V očích jí najednou blýsklo. [Bílá ruka a poklad hradu Handštejna] [In LOC.-eyes to DAT.-her suddenly flashed.]

c. Silmistä paistoi uteliaisuus ... [sla006]

[From ELAT.-eyes shone curiosity ...]

The clauses with intransitive verbs indicating movement or absence thereof, with the EYEphrase as its subject in English (example 5a), correspond semantically to Czech clauses that either display the same syntactic structure or - more frequently (11 instances) - render the OKOphrase as an adverbial (example 5b). The adverbial is formed by a noun phrase with OKO in the instrumental case indicating the means or instrument of 'looking'. ${ }^{12}$ There were no examples of intransitive verbs of movement attested in the Finnish sample. However, there were several cases corresponding to the instrumental use. These occurred together with verbs of 'looking'

\footnotetext{
${ }^{10}$ In Czech the clause in example (4b) is subjectless; there is, therefore, no "competitor" of the verb in terms of information load (cf. Firbas, 1992: 7).

${ }^{11}$ Inessive having a locative meaning "inside", illative meaning "into" and elative meaning "from".

12 The eyes were constructed as instrument (a with-prepositional phrase) in one clause only in the English data: Mortimer scrutinized her with narrowed eyes ... [FSR]
} 
with SILMÄ in the adessive case; this is thus more similar to English both in terms of syntactic and information structure. See example (5c) for Finnish and footnote 11 for English.
a. ... her eyes wandered doubtfully to Ferryman [AEB]
b. "Má bejt ...?" utrhl se, a roztěkanýma očima bloudil po stadiónu. [Metráček] ["So what ...?" he snapped, and with INSTR.-restless eyes wandered around the stadium.”]
c. ... ja vieras tyttö katseli sivusta sameilla silmillään. [sla004]
[....and the foreign girl look sideways with her ADESS.-cloudy eyes.]

There were no Czech clauses in the sample similar to the English occurrences of intransitive verbs indicating change in the shape of the eyes (e.g. rounded in example 6a). In Finnish, we found two examples, both with the verb pyöristyä ('round') (example 6b). Both the syntactic and information structure are divergent here, though.

(6) a. Nick's eyes rounded with remembered horror. [EFJ]

b. Tämä sai Nannan silmät pyöristymään. [sla020]

[This got Nanna's eyes to MA-INF.ILLAT.-round.] ${ }^{13}$

Apart from the correspondences between the English subject and the Czech adverbial as explained above, the high number of OKO-phrases in adverbial position can be accounted for by occurrences where the direction of the gaze is specified by a prepositional phrase with the preposition ' $d o$ ('into') + GEN.-OKO' (example 7a, 11 instances). Four corresponding constructions can be found in the English data (example 7b). Finnish expresses both directions: 'into' (illative case, 18 occurrences) and 'from' (elative case, 3 occurrences). The 'into' direction, similarly as in English and Czech, accounts for occurrences of 'looking into sb.'s eyes' (example 8). The remaining 10 illatives account for cases where something else is happening to the eyes; these typically occur with verbs of an upward movement, as NOUSTA ('rise') in example (8) (for further discussion see Section 5.1.1).

(7) a. Hluboce se nadechla, pohlédla matce do očí a otázala se ... [Vládci sedmihoří] [She took a deep breath, looked her mother in GEN.-the eyes and asked ...]

b. I looked deeply into her eyes. [FRU]

(8) Anisan silmiin nousivat kyyneleet. [sla010]

[Into Anisa's ILLAT.-eyes rose tears.]

There are no corresponding examples in English and Czech for the Finnish elative ('from') constructions illustrated in example (9).

(9) Kyyneleet valuivat peikkomuorin silmistä ja tipahtelivat sileälle kivelle. [sla022] [Tears were running from the old troll woman ELAT.-eyes and were falling on a smooth stone]

As discussed above, most of the adverbial examples in Finnish are accounted for by very precise encoding of location that is inherent to the language system. In addition to the cases discussed above, inessive case (meaning 'in/inside') is represented in our sample by 12 occurrences.

Another factor contributing to the preponderance of the adverbial function of the OKOphrases in Czech and of the subject EYE-phrases in English is related to the difference in the representation of non-finite and verbless supplementive clauses in the two languages. English uses these clauses for backgrounding information on the accompanying circumstances and

\footnotetext{
${ }^{13} \mathrm{MA}$-infinitive is also referred to as III. infinitive
} 
simultaneous actions ${ }^{14}$ while contributing to the impression of the authenticity of the speech (example 10a, with EYE as the subject of a participial clause). In Czech, verbless and non-finite clauses are relatively rare (cf. Malá and Šaldová, 2015). The corresponding adverbial meanings can be expressed by a prepositional phrase (example 10b); simultaneity can be inferred from the coordinative relation between two finite clauses linked by the coordinator $a$ ('and') or juxtaposed (example 24 below). The sequential or simultaneous interpretation of the action performed by the eyes and speech is also supported by the verbal aspect in Czech, with the perfective aspect expressing completed, bounded actions (cf. the verb forms pohlédla 'looked' and otázala se 'asked' in example 7a), and the imperfective aspect actions or processes in progress (cf. dívá se 'is looking' in example 31) (Cvrček et al., 2015: 292). In Finnish, the impression of simultaneity is typically expressed with the E-infinitive in instructive case (6 occurrences) and adjective in essive (5 occurrences), see examples (2a) and (3a).

(10) a. '... I think, though,' the Doctor said, eyes twinkling, 'we'll be able to persuade them ...' [FSR]

b. "Kde ty se tu bereš?” řeknu s vytřeštěnýma očima klukovi stojícímu přede mnou. [Nová láska na obzoru]

["What are you doing here?" I-say with INSTR.-wide-open eyes to DAT.-the boy standing in front of me.]

\subsection{The object}

The difference in frequency of the object function of the EYE- and OKO-phrases between English and Czech is not significant. In both languages, the eyes function most frequently as the object of verbs of 'opening' or 'closing', with the variety of verbs constituting a scale between eyes wide open and closed being broader in Czech: VYTŘEŠTIT, VYPOULIT, VYVALIT, (VY)KULIT, OTEVŘíT, POOTEVŘíT, PŘIMHOUŘIT, ZAMHOUŘIT, PŘIVŘíT, ZAVŘÍT. All these verbs are in the perfective aspect that here conveys a change of state of the eyes. The prefixes poand pri- make it possible to express a lesser degree of 'openness'. Many of these verbs are emotionally coloured. The corresponding English scale comprises merely OPEN, SHUT, CLOSE, KEEP CLOSED. SILMÄ-phrases function as object significantly less frequently in comparison with Czech and English. However, similarly to English and Czech, they are frequently attested with verbs of eye 'opening' (AVATA) and 'closing' (SULKEA).

Another frequent semantic class of verbs which take EYE- and OKO-phrases as their object includes verbs indicating the direction in which the eyes move: DROP, TURN (ON), FIX (ON), KEEP (OFF/ON), REFOCUS, ROLL in English; SKLOPIT, ZDVIHNOUT, ZVEDNOUT, PŘEVRÁTIT / ZVRÁTIT V SLOUP, NEODVRACET, ODLEPIT, OBRÁTIT, POZVEDNOUT, PŘIŠPENDLIT in Czech. The eyes also occur as the object in descriptions which do not directly relate to the adjacent speech. While in the Czech data this is less frequent with only one verb falling in this category (UTÍRAT 'wipe'), in English the range of verbs is broader: WIPE, SHADE, SHADOW, RUB, COVER. The SILMÄ-phrase, similar to English, also frequently occurs in body language descriptions that do not directly relate to speech: eyes are being 'dried' (KUIVATA), 'protected' (SUOJATA), 'covered' (PEITTÄÄ) and 'rubbed' (HIEROA). The SILMÄ-phrase as object also occurs in possessive constructions 'adessive + olla' ${ }^{15}$

\footnotetext{
${ }^{14}$ There were seven non-finite and verbless clauses with the EYE-phrase as the subject in the English sample. In the two Czech verbless clauses in our sample, OKO functioned syntactically as the object.

15 There is no verb 'have' in Finnish. The 'possessor' is in the adessive case followed by the verb 'be' and the 'possessed' is frequently interpreted as 'object', e.g. ...hänella oli tummat kulmakarvat ja silmät ('ADESS.-S/he had dark eyebrows and eyes') [sla010]. However, Hakulinen (2004: § 895-898), for example, classifies these as a subtype of existential constructions.
} 
Our samples are too small for us to describe the lexical patterns with EYE, OKO and SILMÄ systematically; however, based on these limited samples, they seem to frequently participate in phraseological/idiomatic constructions. In Czech, the eyes are used as the object of a number of verbs which are severely restricted in their collocability with other nouns as objects, such as (PŘI/ZA)MHOUŘIT ('narrow, squint'), (VY)TŘEŠTIT ('open wide'), (VY)KULIT or (VY)POULIT ('pop'), PROTŘíT ('rub'), and in idiomatic expressions, for instance OBRÁTIT/PŘEVRÁTIT/ZVRÁTIT oči v sloup ('roll one's eyes upwards'), LHÁT/ZALHAT do očí ('lie, pull the wool over somebody's eyes'). Other idiomatic expressions include 'hodit okem po', which is similar to the Finnish 'iskeä silmä' ('throw an eye on'). The idiom 'believe one's eyes'/ 'věřit svým očím' / 'uskoa silmiään' seems to be common to all three languages.

There were fewer verbs with restricted collocability in English and Finnish; these include for example, STARE, ROLL, BLINK or SIRISTÄÄ ('narrow, squint') and TUIJOTTAA ('stare'). The phrase 'corner of her/his eye' occurred repeatedly and it did not have a semantic or functional equivalent in our data in Czech or Finnish. The English phrase 'keep an eye on' had its Finnish equivalent 'pitää silmällä'.

\section{Fictional eyes: characteristics and narrative functions}

The linguistic description of eye-behaviour accompanying fictional speech shows how characters behave before, during or after speaking. Similarly, as the functions of fictional speech reflect the speech in the "real" world to the extent that it supports the characterisation and the narrative (Leech and Short, 2008; Semino and Short, 2004; Mahlberg et al., 2019), we can expect the degree of faithfulness to "real" eye-behaviour to be on a cline. In Section 5.1, we will focus on the characteristics of fictional eye-behaviour and in Section 5.2 we offer another perspective: we will aim to capture the narrative functions, that is, why the reader's attention is drawn to the characters' eye-behaviour in the first place. The delimitation of the narrative functions is, as can be expected, not straightforward. Unlike in language, there are no standards of form (Beattie, 2004: 79). Despite this variety, we have, as expected, observed similar characteristics and narrative functions across all three languages.

\subsection{Characteristics of fictional eye-behaviour}

Argyle (2010: 5) defines five types and functions of bodily communication: (i) expressing emotions, (ii) communicating interpersonal attitudes, (iii) accompanying and supporting speech, (iv) self-presentation and (v) rituals. Eye-behaviour plays a central role in the first three (Sections 5.1.1 to 5.1.3). Central to eye-behaviour is looking, or 'gaze'. Looking is primarily "a means of perceiving the expressions of others" but "the act and manner of looking also have meaning as signals, showing for example the amount of interest in another person... So gaze is both signal and channel, a signal for the recipient, a channel for the gazer" (Argyle, 2010: 153). There are different aspects of gaze that have been considered: the amount of gaze at other, mutual gaze, looking while talking and while listening, pupil dilation, eye expression, direction of gaze-breaking, or blink-rate (Argyle, 2010: 153-154).

All these aspects are more or less frequently present in fictional texts. Korte (1997: 58) considers the direction and duration of the gaze as the most determining expressive quality. Explicitly expressed mutual gaze and direct eye contact are less frequent than perhaps expected. In our sample, it occurs only eight times in English, nine times in Czech and eight times in Finnish. In Czech, all these occurrences build on verbs of 'looking' - in Czech: 'DÍVAT 
SE/PODÍVAT SE/POHLÉDNOUT + do očl' ('look into eyes'). ${ }^{16}$ In Finnish, the most frequent construction is 'KATSOA/TUIJOTTAA silmiin' ('look/stare into sb.'s eyes'). In English, in addition to 'LOOK/STARE + in/into sb.'s eyes', we have also found examples where mutual gaze is described in other ways, see example (11). A similar example was found for Finnish as well (example 12).

(11) His eyes were still fixed on mine. [FPU]

(12) mä vastasin ja yritin pitää silmäni sen silmissä. Entä muuten? se kysyi [sla019.txt] [I answered and tried to keep my eyes in his INES.-eyes. So what else? he asked...]

Occurrences where one person is looking at another are more frequent than explicitly expressed mutual gaze in all three languages and there is also a greater lexical variation. In English, for example, eyes TURN to, LOOK (up/at), REST/STAY on, REFOCUS on, SCRUTINIZE or simply are (fixed) on, see example (13), with the target of 'looking' being typically the person or their face.

(13) "And then," said the boy, his eyes on Doyle's face, "then you'll shoot me." [AC4]

In Czech, examples include 'HODIT okem po' ('throw an eye on'), 'OBRÁTIT oči po' ('turn eyes to'), 'oči probodávaji' ('eyes drill'), 'oči se přibližuji k' ('eyes are coming close to'). In Finnish, we find 'ISKEÄ silmä' ('throw an eye'), 'KATSOA' ('look'), 'silmät porautuu' ('eyes drill'), 'silmät tutkailee' ('eyes scrutinize').

Avoiding gaze, or gaze breaking, is relatively infrequent in all three languages. In Czech, the specific verb SKLOPIT ('cast down') occurs three times (in two source texts), see example (14).

(14) „Tak promiň,“ sklopím oči a tvářím se nešt'astně a ukřivděně. [Když přijde láska] ["Sorry," I cast down my eyes and look unhappy and aggrieved.]

We do not find corresponding examples in English and Finnish. Several occurrences of gaze breaking in English exemplify situations where the character is showing lack of interest, e.g. (15). There was also an example when a character breaks eye contact in order to make eye contact with someone else, e.g. (16).

(15) "Anybody could walk in." Bella's eyes were fixed on the television screen: she didn't even turn her head. [ACB]

(16) “Oh no, she won’t be angry," Nick said. His eyes slid slyly sideways at Carrie and he started to giggle. [EFJ]

While direction, duration and intensity of the gaze are frequently lexically expressed through the choice of verbs, adverbial constructions and prepositional phrases (see Section 4.1), from the reader's point of perspective, it is often a complex decoding process, as shown in example (17).

(17) Mungo was about to say "yes", when there was a bellow from the direction of the pub. "SHOP!" Lily rolled her eyes. "You see what I'm up against?" she appealed. "Pig ignorant they are." As she turned to serve the impatient customer she added: "I've been in palaces and kings' houses, Mr Stone. [...]" [ACV]

In this example, Lily 'rolls her eyes' expressing both emotion and attitude. Though not explicitly mentioned, Lily is probably also looking at the person she is speaking to, as she is then 'turning away' to serve her customer. Again, though not directly mentioned, we can

\footnotetext{
${ }^{16}$ All these verbs have very similar meanings: DÍVAT SE is a reflexive verb in imperfective aspect meaning 'look', PODÍVAT SE is in the perfective aspect, it is based on the same verb with the prefix po-, which suggests the "looking" is brief and quick, and the perfective POHLÉDNOUT is stylistically slightly archaic and also refers to a brief and quick look.
} 
assume she is also being looked at while speaking. So, while textually only one aspect of the eye-behaviour is described, rolled her eyes, the reader, drawing on their experience of similar situations - both fictional and "real-world", will interpret the text more holistically.

\subsubsection{Expressing emotions}

In addition to eyes, emotions are primarily expressed in the face but also in the body and voice. Emotions may be expressed spontaneously, attempted to be controlled in order to conform to social rules, or concealed for other reasons (Argyle, 2010: 4). Emotions are "classified in terms of dimensions: the dimensions most commonly found are pleasant-unpleasant, and level of arousal" (ibid.: 72). Emotions in the eyes are primarily conveyed through the amount of eye opening, pupil dilation and amount of gaze (ibid.: 73). Facial expressions of emotion are crossculturally similar and, indeed, our data show similarities across the languages rather than differences. However, the linguistic repertoire is extremely rich as we have shown in the previous section and there are clear differences in syntactic preferences between the languages that are also reflected on the semantic level.

Emotions, both pleasant and unpleasant, may be described explicitly and directly in all three languages, as exemplified in example (18).

(18) "No, look -" The big blue eyes were full of pain, innocent, apologetic. "I want to help you, honest ... [AEB]

In example (18), the eyes are described with pre-modifying adjectives in terms of their size and colour $^{17}$ and the emotions are described as if independently as a copula complement. Alternatively, it can be the premodifiers of eyes that convey the emotional states, e.g. steady, icy, or sharp in English; PŘEKVAPENÝ ('surprised'), VYDĚŠENÝ ('scared') and ROZTĚKANÝ ('distracted') in Czech (see example 5a above); and VÄSYMYKSEN TÄYTTÄMÄ ('full of tiredness'), TYHJÄ ('empty') and TOTINEN ('serious') in Finnish. In other cases, eye-behaviour is also described, as in example (6a) above, where Nick's eyes' expression changes, in that his eyes round and the reason for "rounding" is horror, which is similar to example (19) below, where eyes are being nearly closed also with horror.

(19) Tu prosí potřetí: „Bělinko, ženo drahá, polib mě!“ $\mathbf{S}$ hrůzou zamhouřrila Běla oči a políbila hada. [Sedmero krkavců a jiné pohádky]

[And he pleads for the third time: Belinka, my dear wife, kiss me!" Bela closed her eyes with horror and kissed the snake.]

In other cases, we find emotions described directly in the speech and the description of the eyebehaviour amplifies the content. In example (20), the intensity of the moment is communicated by describing the directed gaze.

(20) The monster's yellow eyes looked at me. "I am the unhappiest creature in the world, but I shall fight for my life," he said. [H8G]

Often, however, it is less straightforward to decode the emotion, as in example (21). For the intended reading of this example, the reader needs to be familiar with the fact that "round eyes" (silmät pyöreinä) signal surprise. ${ }^{18}$ For the child reader, contextual situational cues, as in

\footnotetext{
17 The colour of the eyes seems to be of particular importance in Finnish, with colour terms constituting 60 per cent of the modifiers of eyes, e.g. MUSTA, HARMAA, KELTAINEN, UTUISENVIHREÄ, HAALEA or KAISLANVÄRINEN ('black', 'grey', 'yellow', 'hazy green', 'pale', 'reed-coloured'). In Czech the colour and size modifiers of the eyes are rare.

${ }^{18}$ Though not occurring in our sample, 'round eyes' signal surprise in English as well: "She stopped and her eyes grew round with surprise." [BOB]. In Czech, the 'roundness' indicating surprise is encoded primarily through the verb VYKULIT, which has the stem 'kul-', on which words signifying 'round' are based, e.g. adj. kulatý 'round'.
} 
example (21) where Rietta unexpectedly appears on the scene, also help them arrive at the intended reading.

(21) Mitä sinä täällä teet? Vaaputin katsoi silmät pyöreinä Riettaa. [sla021] [What are you doing here? Vaaputin was looking at Rietta with round eyes]

One of the characteristic features of fictional eye-behaviour that occurs frequently across all three languages is the expression of emotion through a light metaphor (see also Section 4.1.1). While pupil dilation is rarely explicitly mentioned in literary texts (Korte, 1997: 58), the light metaphor can be interpreted in relation to the amount of eye opening, expression but also pupil dilation. Light metaphor occurs both with pleasant and unpleasant emotions and can occur in either the speaker's eyes to support the speech, or the listener's eyes to manifest the reaction to what has been said. In the majority of the occurrences, the eyes go from a darker to a lighter state.

In English, the verbs encoding the light metaphor in our sample are SHINE, BURN, FLASH, GLOW, GLEAM, TWINKLE, LIGHT; eyes are also repeatedly described as bright. In Finnish, the verbs are LOISTAA ('shine'), VÄLÄHTÄÄ ('flash'), KIILUA ('glow'), LEIMUTA ('flame'), PAISTAA ('shine'), PALAA ('burn'), PILKAHTAA ('twinkle'), SÄTEILLÄ ('radiate'), SYTTYÄ ('ignite') and TUMMUA ('darken'), the rare case where the metaphor is expressed from light to dark. The noun valo ('light') also occurs (silmissään käy outo valo, 'a strange light appears in the eyes'). In Czech, the verbs include (ZA)SvíTIT ('shine'), ZALESKNOUT ('shine'), ZATŘPYTIT ('glitter'), ZAJISKŘIT ('sparkle'), (ZA)PLÁT ('burn'), BLÝSKAT ('flash'), POBLÝSKÁVAT ('flash'), and also ZATMĚT ('darken') ${ }^{19}$, see examples (22) to (23).

(22) "What do you want?" "Me? Experience, mostly. I want to know things," said Gay. Her eyes, which were very blue, burned for a moment like sapphire lamps. [BMU]

(23) Liito rypisti otsaansa, ja hänen kaislanväriset silmänsä tummuivat harmista. Tietysti kiusasivat, hän tuhahti. [sla002]

[Liito wrinkled his forehead and his reed-coloured eyes darkened with annoyance. - Of course, they bullied, he sniffed.]

(24) „Vašku, nech toho!“ okřikla ho rozzlobeně babička a oči jí hněvivě zaplály. „Pan Havránek nám pouze chce pomoct. [Klobouky z Agarveny]

["Vasek, leave it!" nan shouted at him angrily and her eyes were glowing anger.]

Emotions are also described through other typical accompanying emotional signals: tears or crying $^{20}$ are frequent, but laughter also occurs. In relation to 'tears' and the direction of eyemovement, there are some differences between the languages. While in English 'eyes are full of tears', 'tears fall from eyes', 'eyes fill with tears'; in Czech "slzy vstoupí do očí" ('tears enter into the eyes'), "slzičky se zatřpytí v očích" ('little tears shine in the eyes'), someone 'has tears in the eyes' ('MíT slzy v očích'); in Finnish tears 'fill eyes' ('silmät täyttyy kyynelistä'), 'fall from eyes' ('kyyneleet valuu silmistä') or someone 'has tears in the eyes' (Petellä oli tosiaan kyyneleet silmissä, 'Pete really had tears in his eyes') but typically 'tears' 'rise into someone's eyes', see example (25). Both in Finnish and in Czech, therefore, tears can play a more active role, moving into the eyes.

(25) Hyvää matkaa, hän sanoi ja hänen silmiinsä nousivat kyynelet. [sla010] [Have a good trip, he said and tears rose to his eyes]

The verb NOUSTA ('rise') in Finnish also occurs with ilme ('expression') and katse ('look') that rises into someone's eyes (in illative case which is the case expressing direction) (see the

\footnotetext{
${ }^{19}$ Many of these verbs occur with prefix $z a$-, which signifies short duration and stresses the beginning of the action.

${ }^{20}$ These can be also described less directly as 'wiping her eyes' or 'kosteat silmät' [moist eyes].
} 
discussion in Section 4.1.1). This is different from both English and Czech. In English, the subject of the verbs that have the semantic feature of an upward movement is 'eyes', as in example (26), and in Czech it is the person who moves the eyes upward (ZVEDNOUT, ZDVIHNOUT), as in (27). The upward movement into the eyes appears to contribute to the expression of emotion in Finnish, while in English and Czech the movement of the eyes primarily accompanies and supports speech.

(26) Her huge eyes, gleaming hazel, rose to his, triumph carefully hidden. [APW]

(27) Kája maličko zaváhal, než zdvihl oči: „Já bych, prosím, tuze rád, ale naše maminka by asi nechtěla. [Š́kolák Kája Mařík]

[Kaja hesitated a bit before he lifted his eyes: "I would, very much like to, but my Mum would probably not want me to.’]

\subsubsection{Communicating interpersonal attitudes}

Interpersonal attitudes and relationships are primarily communicated through physical proximity, tone of voice, touch, gaze and facial expressions (Argyle, 2010: 5). In many respects, attitudes are very similar to emotions and may involve exactly the same signals (ibid.: 86). Gaze can communicate, for example, liking through intensity and duration and through mutual gaze (ibid.: 88). Another type of attitude that is being established through gaze is dominance. In an established hierarchy, less gaze but more looking while talking signals dominance, while more gaze and staring other down signal attempts to actively establish dominance (ibid.: 97); see examples (28) and (29). In example (28), Miss Jarman signals her dominance and anger, her gaze is intensive and intimidating - her sharp eyes bored like drills. In example (29), the angry gaze is a response to what has been said. We know that the glowing eyes of the listener have been decoded by the speaker as anger and the speaker responds with a raised warning finger.

(28) "What's that? Speak up. Raise your head. Climbed up what if you please?" "The mooring rope.” Miss Jarman's sharp eyes bored like drills. "Because?” [C85]

(29) "He's finished in Dresden and he's coming back tomorrow." Omi's eyes glowed but Frau Nordern raised a warning finger. [A7A]

Attempts at establishing dominance can be described through expressions of the intensity of the gaze, which is interpreted in conjunction with the speech, as in example (30), where the intensity of the look is described as 'firm' (tiukka), which is supported by the threatening nature of the speech.

(30) ... mä sanoin hiljaa ja katsoin sitä tiukasti silmiin. Sä heräät yks aamu ilman korvia...[sla017]

[I said quietly and looked him firmly in the eyes. You will wake up one morning without ears...]

Example (31) shows a hierarchical relationship in which the person lower on the hierarchy is looking 'with innocent eyes' while example (32) shows gaze aversion as an expression of slight embarrassment.

(31) Kája se dívá bezelstnýma očima do očí profesorových. [Školák Kája Mařík]

[Kája is looking with his innocent eyes into the professor's eyes.]

(32) „Nelichot’ mi,“ sklopí oči. [Tenhle kluk je můj!]

["Don't flatter me," she lowers her eyes.] 


\subsubsection{Accompanying and supporting speech}

Argyle characterizes the 'accompanying and supporting speech' function as speakers and listeners engaging "in a complex sequence of head-nods, glances, and non-verbal vocalizations which are closely synchronised with speech and play an essential part in conversation (Argyle, 2010: 5). This is an area widely researched in linguistics. How this translates in descriptions of fictional speech is a less studied area. Our focus is on eye-behaviour that supports the fictional speech in ways that make it more "authentic", see example (33), where the character's eyes open wide, and the speech is described as high-pitch through the reporting verb vyjekla 'shrieked' modified by the adverb zděšeně ('horrified').

(33) Posléze vytřeštila oči a zděšeně vyjekla: „Jsme tady uvězněni, všude kolem jsou bažiny a zase bažiny." [Vládci Sedmihoří]

[After that she opened her eyes wide and gave a horrified shriek: "We are imprisoned here, there is nothing but swamp around here."]

Eye-behaviour descriptions that directly support the speech may also function instead of a reporting verb (see examples 14, 18, 21, 28 above). However, eye-behaviour descriptions may not only support the speech, but also function as a response to what has been said; see example (29) above.

Argyle (2010: 109) notes that "the main reason that speakers look at listeners is to obtain information, especially to obtain reactions to what has just been said". In fictional texts, this may be subtle as in example (34), where speaker's eyes remain fixed on the addressee during the speech and after the speaker has finished talking, inviting the addressee to respond.

(34) Monks listened with close attention, biting his lip and staring at the floor. "Before your father went to receive that money, he came to see me," continued Mr Brownlow slowly, his eyes fixed on Monks' face. "I never heard that before," said Monks, looking up suddenly, a suspicious expression on his face. [FRK]

The addressee may not, however, always respond in the expected or desired way, as illustrated in example (35).

(35) "I must apologize - I see you know the lady personally." But he had dropped his eyes and lost interest in me. [HGS]

\subsection{Narrative functions}

We have identified three broad functions related to eye-behaviour: a) eye descriptions reveal characters' attitudes and contribute to their characterisation, thus creating a relationship with the reader; b) descriptions of eye-behaviour contribute to the management of the narrative and plot creation, in that they move the narrative forward (this is specifically connected with the verbs of eye 'opening' and 'closing'); and c) eye-behaviour descriptions contribute to the overall development of the plot and description of the situation, rather than directly relating to speech. However, these functions are not easily delimited, as the functions may overlap and combine.

Our first narrative function of conveying attitudes and contributing to characterisation largely overlaps with Argyle's functions of expressing emotions and interpersonal attitudes (see Section 5.1.1 and 5.1.2). However, the function of supporting and accompanying speech (Section 5.1.3) is also largely relevant for characterisation. As discussed above, eye-behaviour may be accompanied by verbs of speaking introducing direct speech or serve as an introductory signal itself. This is often the case in Czech, a language with a high degree of lexical variation in reporting verbs (Nádvorníková, 2020), where verbs from semantic domains other than 
'speaking' can introduce direct speech, see example (36). The omission of the reporting verb is also common in Finnish.

(36) Vivian se zaleskly posměšně oči: „A vešel jste a zeptal jste se na holčičku se sáňkami a ...!" [Pan Tau a tisíc zázraků]

[Vivian's eyes glistened derisively: "And you went in and asked about a girl with a sledge and...!"’]

The function of narrative management and turn-taking has also been discussed already (see Section 5.1.3). As Argyle (2010: 161) notes "[g]aze plays an important role in negotiating when social encounters will start and when they end." This is similar in fictional worlds; looking and movements of the eyes and the lack thereof can be used to signal interaction among participants in conversation, indicating turn-taking (Hoffmannová, 1999: 85), or the pace of the verbal exchange. The most frequent and relevant patterns we have identified include 'LOOK (up) at', 'OPEN one's eyes', 'CLOSE/SHUT one's eyes' and 'FIX one's eyes on' (the Czech and Finnish patterns correspond, for a large part, to the English ones). Where opening the eyes or a gaze directed at the addressee precede the character's direct speech, the eye behaviour appears to be a signal so clear that it generally does not need to be accompanied by a verb of speaking in either language. The reporting verb either follows the direct speech or is missing.

A different narrative-organizing function seems to be associated with eye movement that interrupts the character's direct speech: the pace of the dialogue is slowed down, there is a pause, often described explicitly (see example 37).

(37) “...They had helmets of silver and spears like flames. Ah!” Ilbrec closed his eyes momentarily. "Many battles have I fought, but it is the memory of that one chills me most..." [F99]

Sometimes, the eyes provide the only reaction (example 38) in the communication, substituting for the participant's verbal response.

(38) "Adam," she said. His eyes reacted, coming to meet hers. He remembers who he is, Ruth thought with a pang of relief. [F99]

An action of closing and opening eyes specifically seems to have also a function of finishing a particular scene in the narrative (e.g. eyes closing in example 39), or moving the narrative forward when eyes open, as in (40).

(39) "Yes, father, I will." The King closed his eyes and did not speak again. [GV9]

(40) Neljännen päivän aamuna isä viimein avasi silmänsä. - Pikkuruu Mustanmusta, totisesti, sinä se olet... [sla022]

[On the morning of the fourth day dad finally opened his eyes. - "Pikkuruu Mustanmusta, indeed, it is you...]

Finally, the eyes may contribute to the development of the plot and description of the situation, rather than directly relating to the speech, see example (41).

(41) Joe's eyes rolled around the room, noticing the expensive furniture I had bought recently. [FPU]

Eyes may also be part of other body language descriptions than the categories we have discussed in the previous sections. Although these descriptions do not directly relate to the speech, they are important not only for the context of the situation but also for characterisation; see example (42), where the character blows her curls from her eyes before speaking, a gesture with a less straightforward interpretation, possibly enabling eye contact before the speech. In (43), the gesture will be more familiar, supported by the choice of the reporting verb and the following speech itself. 
(42) Marke kääntyi terävästi. Toiseen poskeen painui kuitenkin hymykuoppa, hän puhalsi kiharat silmiltään. - Mitä? [sla004]

[Marke sharply turned. But in her second cheek a smile dimple appeared, she blew her curls from her eyes. - What?]

(43) Äiti painoi kädet silmiensä eteen ja huokasi: - Voi voi, mitähän tästä oikein seuraa? [sla006]

[Mother pressed her hands in front of her eyes and sighed: Oh no, what will follow from this?]

\section{Conclusions}

In this article we aimed to examine possible meaning-making processes of novice readers, that is children, from a cross-linguistic perspective: English, Czech and Finnish. It has been repeatedly stressed that reading is important for the development of cognitive capacities and evidence shows that stories, in particular, may contribute to enhanced social cognition (Mar, 2018), and therefore fiction texts are thought to be particularly effective in engaging young readers in meaning-making processes (Oakhill et al., 2015, Jerrim and Moss, 2019). Jerrim and Moss (2019: 182) hypothesise, based on previous research, that

the cognitive demands that extended narrative texts make on their readers, through exposure to new vocabulary, different syntactic structures and deeper lexico-semantic networks, may in themselves encourage the development of new competencies and increase reader capacity to handle greater textual complexity.

We assume that it is the relationship with characters that a reader develops that is one of the important meaning-making processes in fiction reading. We examined the complex relationship between the character speech and eye-behaviour in children's fiction, its lexicogrammatical encoding and the links to children's "real-life" experience of similar situations. The language of 'eyes' is important in all three languages and in many respects, the three languages are very similar, for example, the main co-occurring verb types are similar, as are frequent implicit or explicit expressions of emotions, often encoded as a light metaphor in the eyes, with the eyes described as, for instance, shining, burning, flashing or twinkling.

In terms of characteristics and types of eye-behaviour and its narrative functions, we, again, find more similarities than differences between the languages compared - though ways of looking may be in subtle ways different, characters look into each other's eyes, or less frequently, avoid the gaze of the other. Eye-behaviour descriptions support the speech in highlighting the content or the manner of speaking in addition to, or instead of, reporting verbs, or they may even be used instead of a verbal response. Eye-behaviour descriptions can thus, to some degree, compensate for prosodic features and shared context that accompany nonfictional speech. Eye-behaviour in fictional worlds also performs specific additional functions in structuring the narrative and as a device contributes to the creation and development of the characters and the plot.

If fictional communication is to approximate communication in the "real" world, it cannot, therefore, be restricted to verbal code only. We hope to have shown that this applies to children's literature too, with eye-behaviour playing roles parallel to those children encounter in the non-fictional world - expressing emotions, communicating interpersonal attitudes, and accompanying and supporting speech. Just like in the "real" world, a gaze may be "polysemous", and its interpretation may depend not only on the relatively narrow context but also more generally on "real-life" knowledge and cultural background. 
While the similar cultural background and the general narrative features lead to generally congruent types of eye-behaviour being employed in children's books in all three languages, the linguistic means available for the expression of eye-behaviour differ to a large extent, depending on the typological characteristics of the languages in question. The same semantic roles assigned to the eyes (such as the location or instrument) are often expressed by divergent syntactic means. The divergence reflects the relative weight of different word-order principles, the different means of indicating simultaneity, as well as the role of inflection in Finnish and Czech.

In terms of the syntactic encoding one of the differences that emerged from the analysis is greater dynamism, or agency, of eyes in English (the prevalence of the subject position): 'eyes' are much more frequently the 'doer' than in Czech and Finnish. For Finnish, the very precise encoding of 'location' stands out in comparison with English and Czech. This is perhaps not surprising considering the elaborate case system with a number of cases dedicated to expressing local relations. Another feature that emerged in terms of syntactic and grammatical encoding is greater use of non-verbal and participle (in Finnish E-inf.) constructions in Finnish and English that express the simultaneity of the process, that is, eyebehaviour descriptions are more frequently conceptualised as happening at the same time as the speech or other body language. In Czech non-finite verb forms are infrequent; instead, the temporal relations between speaking and looking are indicated by the verbal aspect, which marks the gaze either as an on-going process or as completed action or change of state of the eyes.

This was a pilot study on a limited sample. While the sample was sufficient to show the main tendencies in syntactic and functional distributions of fictional eye-behaviour descriptions across the three languages, larger data samples are needed for more fine-tuned lexical analysis as the lexical encoding seems to suggest subtle differences between the languages. The analysis of narrative strategies was likewise only limited. However, it showed potential for further interdisciplinary collaboration between linguists and literary scholars.

\section{Acknowledgements}

We would like to thank Dr. Hilkka Lindroos and two anonymous reviewers for their valuable comments and suggestions.

\section{References}

Alvstad, C. 2010. Children's Literature and Translation. In Handbook of translation studies, Vol. 1, Y. Gambier and L. van Doorslaer (eds), 22-27. Amsterdam: John Benjamins.

Argyle, M. 2010. Bodily Communication. Florence, UK: Taylor \& Francis.

Beattie, G. 2004. Visible Thought. The New Psychology of Body Language. London: Routledge.

Brattico, P. 2020. Finnish Word Order: Does Comprehension Matter? Nordic Journal of Linguistics, 44(1), 38-70.

Brezina, V., Timperley, M. and McEnery, T. 2018. LancsBox (Version 4) [software]. Available from http://corpora.lancs.ac.uk/lancsbox [Last accessed 17 June 2021].

Burgoon, J.K., Guerro, L.K. and Floyd, K. 2010. Nonverbal Communication. London and New York: Routledge.

Čermáková, A. and Chlumská, L. 2017. Expressing 'place' in Children's Literature: Testing the Limits of the N-gram Method in Contrastive Linguistics. In Cross-linguistic Correspondences. From Lexis to Genre, T. Egan and H. Dirdal (eds), 75-96. Amsterdam: John Benjamins. 
Čermáková, A. and Mahlberg, M. 2018. Translating Fictional Characters - Alice and the Queen from the Wonderland in English and Czech. In The Corpus Linguistics Discourse, A. Čermáková and M. Mahlberg (eds), 223-254. Amsterdam: John Benjamins.

Čermáková, A. and Mahlberg, M. Forthcoming. Gendered Body Language in Children's Literature Over Time. Language and Literature. Special issue edited by M. Burke and K. Coates.

Cvrček, V., Kodýtek, V., Kopřivová, M., Kováŕíková, D., Sgall, P., Šulc, M., Táborský, J., Volín, J. and Waclawičová, M. 2015. Mluvnice současné češtiny 1. Jak se píše a jak mluví. Univerzita Karlova v Praze: Karolinum.

Dušková, L. 2015. From Syntax to Text. The Janus Face of Functional Sentence Perspective. Univerzita Karlova v Praze: Karolinum.

Ebeling, S. O. 2014. An Eye for an Eye? Exploring the Cross-linguistic Phraseology of EyelØye. Nordic Journal of Linguistics 37(2), 225-255.

Firbas, J. 1992. Functional Sentence Perspective in Written and Spoken Communication. Cambridge: CUP.

Hakulinen, A. (ed.). 2004. Iso suomen kielioppi. SKS.

Hoffmannová, J. 1999. "Řeč očí” v konverzační analýze a interakční sociolingvistice. In Dialog v češtině, J. Hoffmannová and O. Müllerová (eds), 84-90. München: Verlag Otto Sagner.

Jerrim, J. and Moss, G. 2019. The Link between Fiction and Teenagers' Reading Skills: International Evidence from the OECD PISA Study. British Educational Research Journal 45(1), 181-200.

Johansson, M. and Håkansson, S. 2019. Corpus Stylistics and Literary Characterisation: Visual Moments in George Eliot. Abstract from 39th Annual Conference of the Poetics and Linguistics Association, Liverpool, United Kingdom.

Korte, B. 1997. Body Language in Literature. Toronto: University of Toronto Press.

Lambert, M. 1981. Dickens and the Suspended Quotation. New Haven, CT and London: Yale University Press.

Lathey, G. 2011. The Translation of Literature for Children. In The Oxford Handbook of Translation Studies, K. Malmkjær and K. Windle (eds), 198-213. Oxford: OUP.

Leech, G. and Short, M. 2007. [ $2^{\text {nd }}$ ed.]. Style in Fiction. Harlow: Longman.

Lindquist, H. and Levin, M. 2008. Foot and Mouth: The Phrasal Patterns of Two Frequent Nouns. In Phraseology: An Interdisciplinary Perspective, S. Granger and F. Meunier (eds), 143-158. Amsterdam: John Benjamins.

Machálek, T. 2020. Kontext: Advanced and Flexible Corpus Query Interface. In Proceedings of The 12th Language Resources and Evaluation Conference, 7003-7008.

Mahlberg, M., Wiegand, V. and Hennessey, A. 2020. Eye Language - Body Part Collocations and Textual Contexts in the Nineteenth-century Novel. In Phraséologie et stylistique de la langue littéraire / Phraseology and Stylistics of Literary Language. Approches interdisciplinaires / Interdisciplinary Approaches, L. Fesenmeier and I. Novakova (eds), 143-176. Berlin: Peter Lang.

Mahlberg, M., Wiegand, V., Stockwell, P. and Hennessey, A. 2019. Speech-bundles in the 19th-century English Novel. Language and Literature, 28(4), 326-353.

Malá, M. and Šaldová, P. 2015. English Non-finite Participial Clauses as Seen Through their Czech Counterparts. Nordic Journal of English Studies, 14(1):232-257.

Mar, R.A. 2018. Stories and the Promotion of Social Cognition. Current Directions in Psychological Science, 27(4), 257-262.

McIntyre, D. 2016. Dialogue: Credibility Versus Realism in Fictional Speech. In The Bloomsbury Companion to Stylistics, V. Sotirova (ed.), 430-443. London: Bloomsbury.

Nádvorníková, O. 2020. Differences in the Lexical Variation of Reporting Verbs in French, English and Czech Fiction and their Impact on Translation. Languages in Contrast 20 (2), 209-234.

Nikanne, U. 2017. Finite Sentences in Finnish: Word Order, Morphology, and Information Structure. In Order and Structure in Syntax I: Word Order and Syntactic Structure, L.R. Bailey and M. Sheehan (eds), 69-97. Berlin: Language Science Press.

Nikolajeva, M. 2014. Reading for Learning. Cognitive Approaches to Children's Literature. Amsterdam: John Benjamins.

Oakhill, J., Cain, K. and Elbro, C. 2015. Understanding and Teaching Reading Comprehension: A Handbook. London: Routledge. 
Page, N. 1988 [2 $2^{\text {nd }}$ ed.]. Speech in the English Novel. Houndmills: MacMillan.

Reynolds, K. 2011. Children's Literature. A Very Short Introduction. Oxford: OUP.

Šebestová, D. and Malá, M. 2019. Expressing Time in English and Czech Children's Literature: A Contrastive N-gram Based Study of Typologically Distant Languages. In Language Use and Linguistic Structure. Proceedings of the Olomouc Linguistics Colloquium 2018, J. Emonds, M. Janebová and L. Veselovská (eds), 469-483. Olomouc: Palacký University.

Sinclair, J. 2004. Trust the Text. Language, Corpus and Discourse. London and New York: Routledge. Stephens, J. 2004. Linguistics and Stylistics. In International Companion Encyclopaedia of Children's Literature, P. Hunt (ed.), 99-111. London: Routledge.

Stockwell, P. and Mahlberg, M. 2015. Mind-modelling with Corpus Stylistics in David Copperfield. Language and Literature, 24(2), 129-147.

Stubbs, M. 2007. Quantitative Data on Multi-word Sequences in English: The Case of the Word World. In Text, Discourse and Corpora, M. Hoey, M. Mahlberg, M. Stubbs and W. Teubert (eds), 163189. London: Continuum.

Toivonen, I. 1995. A Study of Finnish Infinitives (Doctoral dissertation, Brandeis University).

Vaňková, I., Nebeská, I., Saicová-Římalová, L. and Šlédrová, J. 2005. Co na srdci to na jazyku. Kapitoly z kognitivní lingvistiky. Praha, Univerzita Karlova: Karolinum.

Wieçławska, E. 2012. A Contrastive Semantic and Phraseological Analysis of the HEAD-related Lexical Items in Diachronic Perspective. Rzeszow: Wydawnictwo Uniwersytetu Rzeszowskiego.

Wild, K., Kilgarriff, A. and Tugwell, D. 2013. The Oxford Children's Corpus: Using a Children's Corpus in Lexicography. International Journal of Lexicography, 26(2), 190-218.

\section{Appendix}

\section{List of sources:}

\section{ENGLISH}

(based on the BNC User Reference Guide, available at: http://www.natcorp.ox.ac.uk/docs/URG/bibliog.html) Note: The BNC uses text extracts, the size of the extract is included, w.=words

A7A: 33,055 w. from Bury the dead. Carter, Peter. OUP, 1986

ABX: 36,224 w. from Jubilee wood. Hassall, Angela. OUP, 1989

AC4: 34,582 w. from On the edge. Cross, Gillian. OUP, 1989

AC5: 35,699 w. from Paper faces. Anderson, Rachel. Oxford University Press, 1991

ACB: 40,290 w. from The lock. Gates, Susan. OUP, 1990

ACV: 30,655 w. from The forest of the night. Kelly, Chris. OUP, 1991

AEB: 31,816 w. from A twist of fate. Scobie, Pamela. OUP, 1990

ALS: 4,149 w. from Captain Pugwash and the huge reward. Ryan, John. Gungarden Books Rye, 1991

AMB: 31,307 w. from The adventures of Endill Swift. McDonald, Stuart. Canongate Publishing Ltd, 1990

APW: 37,376 w. from Quest for a babe. Hendry, Frances Mary. Canongate Publishing Ltd, 1990

AT4: 44,592 w. from Who, sir? Me, sir? Peyton, K. M. OUP, 1988

B0B: 39,326 w. from The Challenge book of brownie stories. Moss, Robert. MTB Ltd, 1988

B2N: 907 w. from How Miranda flew down Puddle Lane. McCullagh, Sheila. Ladybird Books Ltd, 1991

BMS: 39,028 w. from Gate-crashing the dream party. Leonard, Alison. Walker Books Ltd, 1990

BMU: 38,121 w. from The distance enchanted. Gervaise, Mary. John Goodchild Publ., 1983

BPD: 27,335 w. from Traffic. Masters, Anthony Simon. Schuster Young Books, 1991

C85: 39,351 w. from The first of midnight. Darke, Marjorie. John Murray (Publishers) Ltd, 1989

CA3: 32,781 w. from Lee's ghost. Pulsford, Petronella. Constable \& Company Ltd, 1990

CAB: 38,476 w. from Goodnight Mister Tom. Magorian, Michelle. Puffin Harmondsworth, 1983

CAX: 1,070 w. from Polly and the privet bird. Cartwright, Reg \& Cartwright, Ann. Random House, 1992

CCA: 11,471 w. from A bad spell for the worst witch. Murphy, Jill. Puffin Harmondsworth, 1988

CE0: $\quad 3,400$ w. from Now then Davos. Wiley, M., Harmer, D. \& McMillan, I. Amazing Colossal Press, 1991

CFJ: 15,315 w. from A tale of Anabelle Hedgehog. Lawhead, Stephen. Lion Publishing, 1990

CJJ: 38,787 w. from Space marine. Watson, Ian. Boxtree, 1993

CM1: 36,658 w. from High elves. King, Bill \& Chambers, Andy, Games Workshop, 1993

CM4: 39,412 w. from Inquisitor. Watson, Ian. Boxtree, 1993

EFJ: $\quad$ 40,024 w. from Carrie's war. Bawden, Nina. Puffin Harmondsworth, 1988 
F99: 38,385 w. from Adam's paradise. Rush, A. Macmillan Publishers, 1989

FNS: 6,263 w. from Alice in Wonderland: Oxford Bookworms ed. OUP, 1993

FNY: 10,527 w. from The Brontë story: Oxford Bookworms ed. Vicary, Tim. OUP, 1991

FP5: 5,523 w. from The coldest place on earth: Oxford Bookworms ed. Vicary, Tim. OUP, 1992

FPE: 5,161 w. from Dead Ma's Island: Oxford Bookworms ed. Escott, John. OUP, 1992

FPL: 6,203 w. from The phantom of the opera: Oxford Bookworms edition. Bassett, J. OUP, 1992

FPP: 6,645 w. from Grace Darling: Oxford Bookworms ed. Vicary, Tim. OUP, 1991

FPT: 5,760 w. from Anne of Green Gables: Oxford Bookworms ed. OUP.

FPU: 23,934 w. from Great Expectations: Oxford Bookworms ed. West, Claire. OUP, 1992

FPV: 15,297 w. from Gulliver's travels: Oxford Bookworms ed. OUP.

FR0: 37,862 w. from The highest science. Roberts, G. Virgin London, 1993

FR6: 31,194 w. from Jane Eyre: Oxford Bookworms ed. OUP, 1990

FRD: 6,558 w. from Mary Queen of Scots: Oxford Bookworms ed.. Vicary, Tim. OUP, 1992

FRE: 24,433 w. from Far from the madding crowd: Oxford Bookworms ed. West, C. OUP, 1992

FRK: 26,522 w. from Oliver Twist: Oxford Bookworms ed. Rogers, R. OUP, 1992

FRU: 10,658 w. from Prisoner of Zenda: Oxford Bookworms ed. Hope, A. \& Mowat, D. OUP, 1993

FRX: 6,801 w. from Robinson Crusoe: Oxford Bookworms ed. Mowat, Diane. OUP, 1993

FS2: 10,645 w. from The secret garden: Oxford Bookworms ed. West, C. OUP, 1993

FS3: 9,090 w. from The life and times of William Shakespeare: Oxford Bookworms. Bassett, J. OUP, 1993

FSB: 8,817 w. from The star zoo. Gilbert, H. OUP, 1992

FSJ: $15,070 \mathrm{w}$. from Treasure Island: Oxford Bookworms ed. Escott, John. OUP, 1993

FSK: 8,178 w. from Tooth and claw: Oxford Bookworms ed. "Saki" Border, Rosemary. OUP, 1991

FSL: 4,773 w. from Under the moon: Oxford Bookworms ed. Akinyemi, Rowena. OUP, 1992

FSR: 39,905 w. from White darkness. McIntee, David. Virgin London, 1993

FUB: 16,637 w. from The kingdom under the sea and other stories. Aiken, Joan. Penguin Books, 1989

G1M: 38,774 w. from Lucifer rising. Mortimore, J Lane. A Doctor who books, 1993

GUS: 10,405 w. from The picture of Dorian Gray: Oxford Bookworms ed. Nevile, Jill. OUP, 1989

GV3: 6,140 w. from The piano. Border, Rosemary. OUP, 1989

GV7: 13,411 w. from Dr Jekyll and Mr Hyde: Oxford Bookworms ed. Border, Rosemary. OUP, 1991

GV9: 6,021 w. from The love of a king. Barnes, Trevor \& Dainty, Peter. OUP, 1989

GVM: 6,047 w. from New Yorkers. Mowat, D. \& Hutson, S. OUP, 1991 6-44

GW5: 8,765 w. from Skyjack! Oxford Bookworms ed. Vicary, Tim. OUP, 1989

GW8: 32,881 w. from Tess of the d'Urbervilles: Oxford Bookworms ed. West, Clare. OUP, 1989

GWA: 5,872 w. from Voodoo Island. Duckworth, Michael, OUP. 1989

GWC: 6,371 w. from White death: Oxford Bookworms ed. Vicary, Tim. OUP, 1989

GWH: 18,719 w. from Wuthering Heights: Oxford Bookworms ed. West, Clare. OUP, 1992

H0F: 39,022 w. from The green behind the glass. Geras, Adele. Lions Teen Tracks, 1989

H7V: 19,951 w. from The hound of the Baskervilles: Oxford Bookworms ed. Nobes, Patrick. OUP, 1989

H8G: 9,942 w. from Frankenstein: Oxford Bookworms ed. Nobes, Patrick. OUP, 1992

H8P: 6,365 w. from Sherlock Holmes short stories: Oxford Bookworms edition. West, Clare. OUP, 1989

H93: 1,586 w. from The magician. Escott, John. OUP, 1993

H9E: 2,154 w. from Escape from Planet Zog. Davies, Paul. OUP, 1992

H9U: 20,258 w. from Ghost stories: Oxford Bookworms ed. Border, Rosemary. OUP, 1989

HGS: 43,372 w. from Frankenstein unbound. Aldiss, Brian. New English Library Sevenoaks 1991

HTN: 35,729 w. from A little lower than the angels. McCaughrean, Geraldine. OUP, 1987

HTY: 41,032 w. from The pit. Penswick, Neil. Virgin London, 1993

CH0: 38,786 w. from Krokodil tears. Yeovil, Jack. GW Books Ltd, 1990

CH4: 39,631 w. from Matilda. Dahl, Roald. Puffin Harmondsworth, 1989

CH9: 6,850 w. from The Minpins. Dahl, Roald. Cape London, 1991

CHR: 10,339 w. from Return of the red nose joke book. Green, Rod. Boxtree, 1991

\section{FINNISH}

sla001: $\quad$ Annikki Marjala; Kaamosyön sankarit (1997)

sla002: $\quad$ Annikki Marjala; Korvatunturin salaisuus (1998)

sla003: $\quad$ Hannele Huovi; Salainen maa (1998)

sla004: Hannele Huovi; Tuliraja (1994)

sla005: $\quad$ Marja Luukkonen; Ihmeellinen omenatarha (1997)

sla006: $\quad$ Marja-Leena Tiainen; Jääprinsessa ja jäähykuningas (1996)

sla007: $\quad$ Tittamari Marttinen; Saaran taika (1996) 
sla008: $\quad$ Laila Kohonen; Linnan uhka (1998)

sla009: $\quad$ Marja Luukkonen; Pikku Noita ja Karipeikko (1998)

sla010: $\quad$ Ritva Toivola; Turmankukka (1998)

sla011: $\quad$ Tittamari Marttinen; Seelan aurinkokello (1998)

sla012: $\quad$ Mari Lampinen (Kristina Carlson); Anni tien päällä (1998)

sla013: $\quad$ Mari Lampinen (Kristina Carlson); Annin uusi vuosi (1999)

sla014: $\quad$ Maria Vuorio; Matka, joka aina taittui (1996)

sla015: $\quad$ Mari Mörö; Sakun lintukesä (1998)

sla016: $\quad$ Leena Laulajainen; Sininen soittorasia (1998)

sla017: $\quad$ Tuija Lehtinen; Sara@crazymail.com (1998)

sla018: $\quad$ Taru ja Tarmo Väyrynen; Karri ja öiset valot (1998)

sla019: $\quad$ Laura Lähteenmäki; Rinkkadonna (1998)

sla020: $\quad$ Else Lassila; Korpin laulu (1999)

sla021: $\quad$ Anna-Liisa Haakana; Huityttö ja Pampoika (1999)

sla022: $\quad$ Sirpa Puskala; Pikkuruu Mustanmusta (1999)

sla023: $\quad$ Kari Levola; Sysimusta sukkapyykki (1999)

sla024: $\quad$ Heikki Willamo; Siiri Sopulin syksy (1998)

\section{CZECH}

Note: the year of publication indicates the edition included in the corpus, not necessarily the first year of publication

Batlička, Otakar (1979). Tanec na stožáru. Praha. Albatros.

Burdová, Michaela (2008). Poselství jednorožců. Praha. Fragment.

Čapek, Josef (2003). Povídání o pejskovi a kočičce. Praha. Albatros.

Čechura, Rudolf (2003). Čítanka pro začinající detektivy. Praha. Knižní klub.

Dědeček, Jiří (2013). Jede jede klokan. Praha. Dokořán.

Fischl, Viktor (1993). Strýček Bosko. Brno. Atlantis.

Flos, František (1987). Lovci kožišin. Praha. Volvox Globator.

Foglar, Jaroslav (1968). Hoši od Bobři řeky. Praha. Mladá fronta.

Franková, Hermína - Macourek, Miloš (1994). Arabela. Praha. Svoboda.

Háj, Felix (1990). Školák Kája Mařik [1.-3. díl] Praha. Vyšehrad.

Hlaváčková, Iva (2008). Vládci Sedmihoři. Praha. Fragment.

Hlaváčková, Iva (2008). Terčina bláznivá dobrodružství. Praha. Fragment.

Hlaváčková, Iva (2008). Tajemná země Minor. Praha. Fragment.

Hofman, Ota (1990). Pan Tau a tisíc zázraki̊. Praha. Albatros.

Hofman, Ota (1989). Chobotnice z Čertovky. Praha. Albatros.

Kabátová, Veronika (2006). Když prijide láska. Havlíčkův Brod. Fragment.

Kabátová, Veronika (2006). Tenhle kluk je můj! Havlíčkův Brod. Fragment.

Kabátová, Veronika (2006). Nová láska na obzoru. Havlíčkův Brod. Fragment.

Kárník, Zdeněk (2004). Bílá ruka a poklad hradu Handštejna. Praha. Dokořán.

Klimtová, Vítězslava (2006). Obyčejný skřitek. Kostelní Vydří. Karmelitánské nakladatelství.

Klimtová, Vítězslava (2006). O statečném skřitku Drnovci. Kostelní Vydří. Karmelitánské nakladatelství.

Klimtová, Vítězslava (2006). Bukvínkova kouzelná pišstalka. Kostelní Vydří. Karmelitánské nakladatelství.

Koutská, Blanka - Němcová, Božena (2000). Sedmero krkavců a jiné pohádky. Praha. Vyšehrad.

Kriseová, Eda (1992). Terezka a Majda na horách [1. část] Brno. Atlantis.

Kriseová, Eda (1992). Terezka a Majda na horách [2. část] Brno. Atlantis.

Kriseová, Eda (1992). Terezka a Majda na horách [4. část] Brno. Atlantis.

Kriseová, Eda (1992). Terezka a Majda na horách [3. část] Brno. Atlantis.

Kühnl, Daniel (2008). Správná parta a zrušená kletba. Praha. Fragment.

Kühnl, Daniel (2007). Správná parta a kouzelný míč. Praha. Fragment.

Macourek, Miloš (1971). Pohádky. Praha. Mladá fronta.

Macourek, Miloš (1982). Mach a Šebestová. Praha. Albatros.

Merhoutová, Eliška (2000). Indické pohádky a bajky. Praha. Vyšehrad.

Myslíková, Míla (2002). V dobrém jsme se sešli... Brno. L. Marek.

Neuwirth, Štěpán (2000). Paseka živých jelenů. Ostrava. Repronis.

Pavlíček, František (2003). Princ Bajaja. Brno. Atlantis.

Pavlíček, František (2003). Tři ořišky pro Popelku. Brno. Atlantis.

Pavlíček, František (2003). Královský slib. Brno. Atlantis.

Poláček, Karel (1967). Bylo nás pět. Praha. Odeon. 
Pospíšilová, Zuzana (2006). Moudrá sova Rozárka. Havlíčkův Brod. Fragment. Prášková, Markéta (2013). Klobouky z Agarveny 3. Praha. Grada.

Prášková, Markéta (2007). Klobouky z Agarveny 1. Havlíčkův Brod. Fragment.

Procházková, Helena (2009). Mince krále Ašóky. Praha. Baronet.

Renč, Ivan (2006). Tajemství posledního večera. Kostelní Vydří. Karmelitánské nakladatelství.

Rubík, Jan (2005). O princezně Mirandolíně. Kostelní Vydří. Karmelitánské nakladatelství.

Rudolf, Stanislav (1985). Metráček. Praha. Olympia.

Rudolf, Stanislav (1985). Nebreč, Lucie. Praha. Československý spisovatel.

Selucký, Oldřich (2004). Pavel, dobrodruh víry. Kostelní Vydří. Karmelitánské nakladatelství.

Semerád, Martin (2000). Čarodějovy pohádky. Praha. Autobus.

Skřivánek, Jaromír (1998). Kouzelný hadí kámen. Praha. Knižní klub.

Stanovský, Vladislav (2005). Jak chodil Kristuspán se svatým Petrem po světě. Kostelní Vydří. Karmelitánské nakladatelství.

Šmejkal, Roman (1996). Zvírátková abeceda. Praha. Knižní klub.

Troska, Jan Matzal (1997). Peklo v ráji. Praha. Leprez.

Vladislav, Jan (1999). Pohádky paní Meluzíny. Brno. Atlantis.

Vodňanský, Jan (1997). Velký drači propadák. Praha. Volvox Globator.

Vopěnka, Martin (1998). Pohádky Větrných hor. Praha. Knižní klub.

Vyskočil, Ivan (1990). Malý Alenáš. Praha. Práce.

Wenig, Adolf (1997). Pověsti o hradech. Praha. Volvox Globator.

Werich, Jan (1977). Fimfárum. Praha. Albatros.

Unknown (1998). Obrázky z Bible. Praha. Vyšehrad.

Authors' addresses

Anna Čermáková

The Institute of the Czech National Corpus,

Faculty of Arts,

Charles University nám. Jana Palacha $1 / 2$

CZ-116 38 Praha 1

Czech Republic

anna.cermakova@ff.cuni.cz

Markéta Malá

Department of English Language and Literature,

Faculty of Education,

Charles University,

Celetná 13,

CZ-116 39 Praha 1

Czech Republic

marketa.mala@pedf.cuni.cz 